\title{
Effect of NPK Fertilization Method on the Physiology and Fruit Products of Myristica fragrans in North Maluku, Indonesia
}

\author{
Wawan Sulistiono $^{1^{*}}$, Abubakar Ibrahim ${ }^{1}$, Bayu Suwitono ${ }^{1}$ \\ Himawan Bayu Aji ${ }^{1}$, Abdul Wahab ${ }^{1}$, Muhammad Taufiq Ratule ${ }^{2}$ \\ and Made Jana Mejaya ${ }^{3}$
}

${ }^{1}$ Assessment Institute for Agricultural Technology of North Maluku, Indonesia. ${ }^{2}$ Indonesian Center for Agricultural Technology Assessment and Development, Bogor, Indonesia. ${ }^{3}$ Indonesian Legumes and Tuber Crops Research Institute (ILETRI), Jl. Raya Kendalpayak Km. 8., P.O.Box 66, Malang 65101, East Java, Indonesia.

Authors' contributions

This work was carried out in collaboration among all authors. Author WS designed the study, performance the analysis and the wrote the first draft of the manuscript. Author Al conducts treatment and wrote methods and tidies up the draft according to the journal template. Author BS prepared the materials, tools and applied the treatment. Author HBA prepared the materials and tools. Authors AW and MTR managed the study and helped in the interpretation of the results. Author MJM managed the writing from manuscripts and literature searches. All authors read and approved the final manuscript.

Article Information

DOI: $10.9734 / A R R B / 2021 / v 36 i 330350$ Editor(s):

(1) Dr Paola Angelini, University of Perugia, Italy. Reviewers:

(1) Besufekad Belayneh Bassa, Hawassa University. Ethiopia.

(2) K Thyagaraju, Sri Venkateswara University, India. (3) Karen Andreon Viçosi, Universidade Federal do Espírito Santo, Brasil. Complete Peer review History: http://www.sdiarticle4.com/review-history/67002

Original Research Article

Received 23 January 2021 Accepted 30 March 2021 Published 05 April 2021

ABSTRACT

Aims: The objective of this study was to determine the optimal fertilizing method and NPK fertilizer dosage for plant physiology and nutmeg yield.

Study Design: The experimental design was a completely randomized block design (CRBD) in a $4 \times 3$ factorial arrangement with three replicates. The first factor was four NPK fertilizer doses: 1, 1.5, 2.0, and $2.5 \mathrm{~kg}$ NPK (15:15:15)/tree/year. The second factor was the manner of fertilizer application: (1) fertilized in spot, (2) fertilized in-furrow trenches trunked and (3) fertilized in hole. 
Place and Duration of Study: The research was conducted in Tobelo North Halmahera $\left(1^{\circ} 44^{\prime} 45.3^{\prime \prime}-1^{\circ} 44^{\prime} 54.4^{\prime \prime} \mathrm{N}, 127^{\circ} 59^{\prime} 54.4^{\prime \prime}-127^{\circ} 59^{\prime} 53.2^{\prime \prime} \mathrm{E}\right)$, North Maluku, Indonesia from January 2019 to May 2020.

Methodology: The nutmeg trees used was 30 years old. The population of trees plants in the study area was 40 trees. Observation parameters on leaves are chlorophyll a, b and total, nitrate reductase activity (NRA), N, P, K, proline content, number of young and old fruits.

Results: The fertilization treatment with the fertilizer application method into the crack/hole fertilizer with a dose of $2.5 \mathrm{~kg}$ NPK significantly produced high levels of chlorophyll a, chlorophyll b, total chlorophyll of leaves and old fruit. The number of old fruits is positively correlated with chlorophyll a content $\left(0.615^{*}\right)$, chlorophyll b $\left(0.663^{*}\right)$, total chlorophyll $\left(0.634^{*}\right)$ and number of young fruits $\left(0.748^{* *}\right)$. The application of fertilizer hole produces plants that recover quickly from drought stress, as evidenced by the highest proline content.

Conclusion: NPK fertilization using the hole method and at doses of $2.0-2.5 \mathrm{~kg} / \mathrm{tree} / \mathrm{year}$ are recommended for improving plant physiology and yield.

Keywords: NPK fertilization method; nutmeg; physiology; proline; yield.

\section{INTRODUCTION}

Indonesia is the largest nutmeg producer with a $75 \%$ role in the world, followed by Granada with $20 \%$ with products in the form of nutmeg and mace. Nutmeg in Indonesia grows and produces in several provinces, namely, North Maluku, Maluku, West Papua, North Sulawesi, and Aceh [1]. In North Maluku, the center of producing area, nutmegs are the main income of the regional economy. Nutmeg plants are cultivated in the yard system, mixed garden with coconut, and homogeneous garden of people's gardens. Therefore, optimal productivity is important to increase production volume, farmers' income, and export.

To fulfill optimal production, good cultivation management is needed. The NPK macro nutrients become the main component to determine the growth, yield, and quality of crop yields. Balancing NPK is a key strategy in cultivation to increase crop productivity [2] or fresh crop yields [3].

NPK fertilization combined with compost and manure not only increases plant biomass but also the content of essential oils and the aroma of the Thymus daenensis plant [4]. Nitrogen as a component of aminoacids, nucleic acids, tructure of chlorophyll, the light harvesting component of photosynthesis. Phosphore is the primary one being the storage and transfer of energy for example adenosine diphosphate (ADP) and adenosine triphosphate (ATP) on plant metabolism (photosynthesis, respiration, protein, and nuclear acid, nutrient, transport). Potassium is the primary osmolyte and ion involved in cell membrane dynamics, the regulation of structure and maintenance of turgor and osmotic equalibrum. It also plays important roles in the regulation and activation of enzyme activity [5].

To get optimal fertilization results, it requires the right application method and dosage of fertilization. According to the report Meng et al. [6] the effectiveness of fertilization in terms of yields and the efficiency of nitrogen uptake, determined by the manner of application or placement of chemical fertilizers. The optimal fertilizer dosage also determines the yield and quality. Report of Tsialtas et al. [7] states that the optimal $\mathrm{K}$ dose increases leaf physiology, fiber yield and Catton (Gossypium hersutum) fiber length. In addition, the right dose of NPK fertilizer increases growth parameters, growth and kenaf biomass parameters [8]. The fertilizing dose factor also determines root development such as root length and root surface area [9].

Based on the importance of the dosage and method of fertilization, this study aims to determine the appropriate dosage and application method of NPK (15:15:15) fertilizer to increase nutmeg fruit yield and the physiological properties of the leaves

\section{MATERIALS AND METHODS}

\subsection{Location and Materials}

The field experiment located in Wari Village Tobelo, North Halmahera, Indonesia (1 ${ }^{\circ} 44^{\prime} 45.3^{\prime \prime}-$ $1^{\circ} 44^{\prime} 54.4^{\prime \prime} \quad \mathrm{N}, \quad 127^{\circ} 59^{\prime} 54.4^{\prime \prime}-127^{\circ} 59^{\prime} 53.2^{\prime \prime} \quad \mathrm{E}$, elevation $30 \mathrm{~m}$ ). Soil chemical characteristics of the research location for $\mathrm{pH}$, total $\mathrm{N}$, available $\mathrm{K}$ and $\mathrm{P}\left(\mathrm{P}_{2} \mathrm{O}_{5}\right)$ were 6.62, $0.12(\%), 119 p p m$ and $62 \mathrm{ppm}$ respectively. The study was conducted in 
Januari 2019 - May 2020. The nutmeg trees used was 25-30 years old. The nutmeg variety used was Tobelo 1 which originated it's from Tobelo, North Halmahera District, North Maluku Province, Indonesia.

The place of research was a farmer's garden with a tree spacing of $8 \mathrm{~m} \times 8 \mathrm{~m}$. The population of trees plants in the study area was 40 trees. The fertilizer used was NPK Phonska 15:15:15 with a percentage of the contents of $\mathrm{N}, \mathrm{P}$ and $\mathrm{K}$ was 15,15 and $15 \%$ respectively. The tool used to make fertilizer holes in which a size of $50 \mathrm{~cm} \mathrm{x}$ $40 \mathrm{~cm}$ x $40 \mathrm{~cm}$ was a hoe. Hoes was also used to make circular furrow fertilizer holes under the tree's outer canopy and fertilizing locally, (spot of applied fertilizer). Trees treated were given paint colored and numbered trees according to the treatment combination number.

The study of chlorophyll content, nitrate reductase activity (NRA), proline were carried out at Agronomy Departement, Crop Production Management Laboratory of Agriculture Faculty of Universitas Gadjah Mada, Yogyakarta Indonesia from June 2019 to February 2020. The study of soil $\mathrm{pH}$ and $\mathrm{N}, \mathrm{P}, \mathrm{K}$, the content of left $\mathrm{N}, \mathrm{P}, \mathrm{K}$ were carried out at Soil, Crop, Fertilizer and Water Laboratory of Assessment Institute for Agricultural Technology of Yogyakarta from June 2019 to February 2020.

\subsection{Experimental Design and Application of NPK Fertilizer}

The experimental design was a Completely Randomized Block Design (CRBD) arranged in 4 $x 3$ factorial with three replications. The first factor was the dosage of NPK (15:15:15) fertilizer application consisting of four-levels namely: $1 \mathrm{~kg}$ (50\% of recommended dosage), $1.5 \mathrm{~kg} \mathrm{(75 \%} \mathrm{of}$ recommended dosage), $2.0 \mathrm{~kg}(100 \%$ of recommended dosage) and $2.5 \mathrm{~kg} \mathrm{NPK} /$ tree/year $(125 \%$ of recommended dosage). The recommended dosage was $300 \mathrm{~kg}$ Urea +200 $\mathrm{kg} \mathrm{SP}-18+100 \mathrm{~kg} \mathrm{KCl} \mathrm{ha}{ }^{-1}[10]$. The second factors were methods of NPK fertilizer application consisted of three levels namely: method $1=$ application at a certain point with a hoe (fertilizing at six points); method $2=$ application at a circular furrow fertilizer holes under the tree's outer canopy; and method 3 = application at a fertilizer hole "rorak" in which a size of $50 \mathrm{~cm} \mathrm{x} 40 \mathrm{~cm} \times$ $40 \mathrm{~cm}$.

Field experiments arranged using 12 combinations repeated in 3 blocks, resulted that the total treated trees were 36 trees. The fertilzer (NPK Phonska 15:15:15) was applied in two stages. The first stage was applied as much as $1 / 3$ of the dose given at the beginning of the rainy season (April); the second stage as much as $2 / 3$ of the dose was given two months later (June). The application of fertilizer according to treatment. In fertilizer application, the method of sowing was in the ring furrow hole under the canopy (method 2), fertilizer place made by making a circular hole groove as deep as $20 \mathrm{~cm}$ using a hoe. After fertilizer sown in the fertilizer flow, fertilizer covered with soil. In application at a certain point with a hoe (method 1), the fertilizer place was a certain point with a hoe in at six points and after that covered with soil. The same way did during the second fertilization. At the fertilizing treatment was inserted into a fertilizer hole (method 3), fertilizer sowed on the fertilizer hole. The fertilizer hole was made previously with the location under the outer canopy. The number of fertilizer holes per plant was 4 . The dose of fertilizer application to plants was according to treatment $(50,75,100$, and $125 \%$ of recommended dosage).

\subsection{Measurements}

The parameters observed were: leave chlorophyll content (a, b, and total chlorophyll), NRA of leaves, the concentration of N, P and $K$ leaves, proline content of leaves, number of young fruits and number of old fruits (per branch twig). Criteria for young fruit are $4 \mathrm{~cm}$ diameter fruit and green flesh. The criteria for the old fruit are fruits with a diameter of $>4 \mathrm{~cm}$ and yellow flesh (old fruit flesh). Observation starts one month after fertilization treatments, 40 days after fruiting until the fruit was seven months old. Chemical analysis of N, P, K of leave carried out by using the procedure issued by Yoshida et al. [11]. Leaf chlorophyll content was measured using the method of Wintermans and de Mots [12]. Leaf NRA content was measured using Hartiko's methods was modified by Indradewa et al. [13]. Leaf proline content carried out by using the "ninhydrin" procedure by Bates et al. [14].

\subsection{Statistical Analysis}

Data were submitted to analysis of variance of CRBD using SAS 19 for Windows. If there was an interaction between treatment, a comparison of the interaction effect was made. Otherwise, treatment mean effects were compared based on Duncan's multiple range test at $P<0.05$. To find out the correlation between the parameters of a 
correlation analysis test was performed. Soil analysis data are written in text form in the methodology as a result.

\section{RESULTS AND DISCUSSION}

\subsection{Effect of NPK Fertilizer Treatment on Chlorophyll and Leaf NRA}

The application doses of NPK fertilizer which interacted with fertilization method significan increased the chlorophyll a $(P<0.01)$, chlorophyll b $(P<0.01)$, total chlorophyll $(P<0.05)$ and the leaf NRA $(P<0.01)$. The fertilizer application dose 1-2 $\mathrm{kg} \mathrm{NPK/tree/year} \mathrm{applied} \mathrm{on} \mathrm{the} \mathrm{fertilizer} \mathrm{hole}$ (manner of fertilizing 3) can be used to improve plant physiology. This is because in addition to the small volume of fertilizer required, it also produces the high leaf chlorophyll content and NRA of leaves (Table 1). These results indicate that the proper fertilization method can increase leaf chlorophyll and NRA. In this case on land that is not rocky, fertilizing by making a fertilizer hole $(40 \mathrm{~cm} \times 40 \mathrm{~cm} \times 50 \mathrm{~cm})$ with a dose of $2 \mathrm{~kg}$ NPK(15:15:15)/tree/year can be applied.

The interaction of NPK fertilization dose of $1-2 \mathrm{~kg}$ NPK/tree/year and fertilizer application at a fertilizer hole determines leaf physiology, namely an increase in chlorophyll a, b, and total leaf chlorophyll (Table 1). This result is in line with the report of Spulak et al. [15] stated that the application of NPK fertilizer increased the chlorophyll of leaves. The report of Long et al. [16] also stated that the application of NPK fertilization at a certain dose significantly increased the chlorophyll content of leaves (rice). According to Long et al. [16] optimal chlorophyll content and determining plant growth is determined by the appropriate application of chemical fertilization (NPK).

The presence of chlorophyll a $\left(\mathrm{C}_{55} \mathrm{H}_{72} \mathrm{MgN}_{405}\right)$ is important to attract electrons from sunlight for photosynthesis (wavelengths $429 \mathrm{~nm}$ and 629 $\mathrm{nm}$ ). The main function of chlorophyll is as the primary electron donor in the photosynthetic electron transfer chain. In general, the presence of chlorophyll a, chlorophyll b, and total chlorophyll are essential elements for photosynthesis $[17,18]$. High chlorophyll content in leaves also indicates that the plant is still optimally growing and does not experience growth disturbances due to drought stress [18]. Drought stress will reduce the chlorophyll $a, b$ and total chlorophyll content [19]. High leaf chlorophyll content indicates that the plant has optimal growth to avoid drought stress $[18,19]$.
The results of this research show that fertilizing in the "rorak" fertilizer hole is a method of avoiding drought stress. This was indicated by the production of the highest leaf proline, which was significantly different from the application of manual system fertilization (Table 3).

NPK fertilization using the method of placed in the fertilizer hole (rorak) at a dose of NPK 15:15:15 2kg/tree/year produced the highest NRA of leaves compared to other combinations (Table 1). This shows that the fertilization fulfills the fertilization principle, namely the right place/application and dose. Besides that NRA is determined by the nitrogen source, namely NPK Phonska 15:15:15. This result is in line with several reports, namely leaf NRA correlates with $\mathrm{NO}_{3}{ }^{-}$content in soil and stem tissue [20]. Nitrogen sources such as $\mathrm{NaNO}_{3}{ }^{-}$produced the highest of NRA compared to nitrogen sources of $\mathrm{NH}_{4} \mathrm{Cl}$ and Urea [21]. The increase in $\mathrm{N}$ accumulation in the root or leaf tissue by fertilization stimulated NRA in both leaves and roots 13 and $42 \%$, respectively [22]. Mensah et al. [23] that NPK fertilization (15:15:15) at a certain dose range significantly increased the number of leaves, plant height, and leaf area of the Punica granatum plant.

\subsection{Effect of NPK Fertilizer Treatment on Content of N, P, K and Leaf Proline}

There was a significant interaction between application doses of NPK fertilizer and fertilization method application in content of $\mathrm{N}$ total and $\mathrm{P}$ of leave. The manner of fertilizing 2 (the application was sown at the circular hole grooves under the canopy) at the doses of $2 \mathrm{~kg}$ NPK (15:15:15)/tree/year highest increased on the $\mathrm{N}$ total of leave. However, the $\mathrm{P}$ concentration in leaves increased significantly (the highest concentration) under effect of fertilizer application in the 3rd manner at the doses of $1.5 \mathrm{~kg} \mathrm{NPK}(15: 15: 15) /$ tree/year (Table 2). These results indicate that aim to increase the nutrient content of $\mathrm{N}$ or $\mathrm{P}$ in leaves can be done with the right fertilization method and dose.

The manner of NPK fertilizer application had significant effect $(P<0.01)$ on $K$ concentration in leave. The application of NPK fertilizer to the hole with a size of $50 \mathrm{~cm} \times 40 \mathrm{~cm} \times 40 \mathrm{~cm}$ resulted in a significantly higher $K$ leaf concentration compared to fertilization method 1. This fertilization method (fertilization method 3) also affected the increase in the highest leaf proline content, which was significantly different 
from other fertilization methods. The leaf proline concent was also affected with dose of NPK fertilization application treatment. At the $2.5 \mathrm{~kg}$ NPK/tree/year dose influenced produced the highest leaf proline content. At the hight proline content level indicated that the physiological mechanism to recovery from drought stress or environmental stress. These results indicate that the function of the fertilizer hole (rorak) can keep the plants from experiencing severe drought stress. Making these fertilizer holes and placing the NPK fertilizer there, causes the plants to produce the highest proline to recovery the environment's drought stress (Table 3).

The effect of NPK fertilization on increasing leave physiology of plant is in line with the report of Milosevic and Milosevic [24] stated that NPK fertilization increased the $P$ content of leaves in certain varieties of apple plants. Thus NPK fertilization at certain doses and compositions is needed as a new cultivation management

Table 1. Interaction effect of NPK fertilizer application methods and doses levels on chlorophyll \& NRA of leaves at 4 months after treatment

\begin{tabular}{|c|c|c|c|c|c|}
\hline Methods & Doses & $\begin{array}{l}\text { Chlorohlyll } \\
\text { a of leaves } \\
\left(\mathrm{mg} \mathrm{g}^{-1}\right)\end{array}$ & $\begin{array}{l}\text { Chlorohlyll } \\
\text { b of leaves } \\
\left(\mathrm{mg} \mathrm{g}^{-1}\right)\end{array}$ & $\begin{array}{l}\text { Total } \\
\text { chlorohlyll } \\
\left(\mathrm{mg} \mathrm{g}^{-1}\right)\end{array}$ & $\begin{array}{l}\text { Leaves NRA } \\
\left(\mu \mathrm{mol} \mathrm{NO}_{2} \mathrm{~h}^{-1}\right)\end{array}$ \\
\hline Method 1 & $1 \mathrm{~kg} \mathrm{NPK/tree/year}$ & $0.463 \mathrm{~b}-\mathrm{f}$ & $0.393 \mathrm{c}-\mathrm{f}$ & $0.856 \mathrm{bc}$ & $0.990 \mathrm{a}-\mathrm{c}$ \\
\hline Method 1 & $1.5 \mathrm{kgNPK} /$ tree/year & 0.517 a-d & 0.465 a-d & $0.891 \mathrm{a}-\mathrm{c}$ & $0.946 \mathrm{a}-\mathrm{c}$ \\
\hline Method 1 & 2kgNPK/tree/year & $0.433 \mathrm{c}-\mathrm{g}$ & $0.411 \mathrm{~b}-\mathrm{e}$ & $0.844 \mathrm{~b}-\mathrm{d}$ & $1.083 \mathrm{a}-\mathrm{c}$ \\
\hline Method 1 & 2.5NPK/tree/year & $0.554 a b$ & 0.489 a-c & $1.042 a b$ & $0.661 \mathrm{bc}$ \\
\hline Method 2 & $1 \mathrm{~kg} \mathrm{NPK/tree/year}$ & $0.409 \mathrm{e}-\mathrm{g}$ & $0.383 \mathrm{~d}-\mathrm{f}$ & $0.792 \mathrm{~cd}$ & $0.617 \mathrm{c}$ \\
\hline Method 2 & $1.5 \mathrm{kgNPK} /$ tree/year & $0.379 \mathrm{fg}$ & $0.347 \mathrm{~d}-\mathrm{f}$ & $0.792 \mathrm{~cd}$ & $0.617 \mathrm{c}$ \\
\hline Method 2 & 2kgNPK/tree/year & $0.403 \mathrm{e}-\mathrm{g}$ & $0.407 \mathrm{~b}-\mathrm{e}$ & $0.831 \mathrm{~b}-\mathrm{d}$ & $0.577 \mathrm{c}$ \\
\hline Method 2 & 2.5NPK/tree/year & $0.322 \mathrm{~g}$ & $0.298 \mathrm{f}$ & $0.619 \mathrm{~d}$ & $0.885 \mathrm{a}-\mathrm{c}$ \\
\hline Method 3 & $1 \mathrm{~kg} \mathrm{NPK/tree/year}$ & $0.595 \mathrm{a}$ & $0.519 a$ & $1.114 \mathrm{a}$ & $0.647 \mathrm{bc}$ \\
\hline Method 3 & $1.5 \mathrm{kgNPK} /$ tree/year & $0.402 \mathrm{e}-\mathrm{g}$ & $0.382 \mathrm{~d}-\mathrm{f}$ & $0.784 \mathrm{~cd}$ & $0.955 a-c$ \\
\hline Method 3 & 2kgNPK/tree/year & $0.501 \mathrm{a}-\mathrm{e}$ & $0.453 \mathrm{a}-\mathrm{d}$ & $0.954 \mathrm{a}-\mathrm{c}$ & $1.515 \mathrm{a}$ \\
\hline Method 3 & 2.5NPK/tree/year & $0.537 \mathrm{a}-\mathrm{c}$ & $0.497 a b$ & $1.033 a b$ & $0.986 \mathrm{a}-\mathrm{c}$ \\
\hline \multicolumn{6}{|c|}{$\begin{array}{l}\text { Remarks: Different letters in same column represents significant differences by Duncan's Multiple Range Test at } \\
5 \% \text { level. } \\
\text { Method } 1 \text { = fertilizer application at a certain point with a hoe (fertilizing at six points) } \\
\text { Method } 2 \text { = fertilizer application at the circular hole grooves under the canopy }\end{array}$} \\
\hline
\end{tabular}

Table 2. Interaction effect of NPK fertilizer application methods and doses levels on N and P of leaves at 4 months after treatment

\begin{tabular}{|c|c|c|c|}
\hline Methods & Doses & $\% \mathrm{~N}$ total of leaves & $\%$ P of leaves \\
\hline Method 1 & $1 \mathrm{~kg} \mathrm{NPK/tree/year}$ & $1.300 \mathrm{~b}-\mathrm{e}$ & $0.400 \mathrm{~b}$ \\
\hline Method 1 & $1.5 \mathrm{kgNPK} /$ tree/year & $1.290 \mathrm{c}-\mathrm{e}$ & $0.140 \mathrm{~b}$ \\
\hline Method 1 & 2kgNPK/tree/year & $1.397 \mathrm{~b}-\mathrm{d}$ & $0.176 \mathrm{~b}$ \\
\hline Method 1 & 2.5NPK/tree/year & $1.417 \mathrm{a}-\mathrm{c}$ & $0.236 \mathrm{~b}$ \\
\hline Method 2 & $1 \mathrm{~kg} \mathrm{NPK/tree/year}$ & $1.280 \mathrm{c}-\mathrm{e}$ & $0.246 \mathrm{~b}$ \\
\hline Method 2 & $1.5 \mathrm{kgNPK} /$ tree/year & $1.430 a b$ & $0.186 b$ \\
\hline Method 2 & $2 \mathrm{kgNPK} /$ tree/year & $1.537 \mathrm{a}$ & $0.216 b$ \\
\hline Method 2 & 2.5NPK/tree/year & $1.240 \mathrm{e}$ & $0.176 \mathrm{~b}$ \\
\hline Method 3 & $1 \mathrm{~kg} \mathrm{NPK/tree/year}$ & $1.260 \mathrm{de}$ & $0.180 \mathrm{~b}$ \\
\hline Method 3 & $1.5 \mathrm{kgNPK} /$ tree/year & $1.283 \mathrm{c}-\mathrm{e}$ & $0.700 \mathrm{a}$ \\
\hline Method 3 & $2 \mathrm{kgNPK} /$ tree/year & $1.403 \mathrm{bc}$ & $0.213 b$ \\
\hline Method 3 & 2.5NPK/tree/year & $1.367 \mathrm{~b}-\mathrm{e}$ & $0.293 b$ \\
\hline \multicolumn{4}{|c|}{$\begin{array}{l}\text { *Remarks: Different letters in same column represents significant differences by Duncan's Multiple Range Test at } \\
5 \% \text { level. }\end{array}$} \\
\hline
\end{tabular}


Table 3. Effect of NPK fertilizer application methods and doses levels on leaf $\mathrm{K}$ dan proline

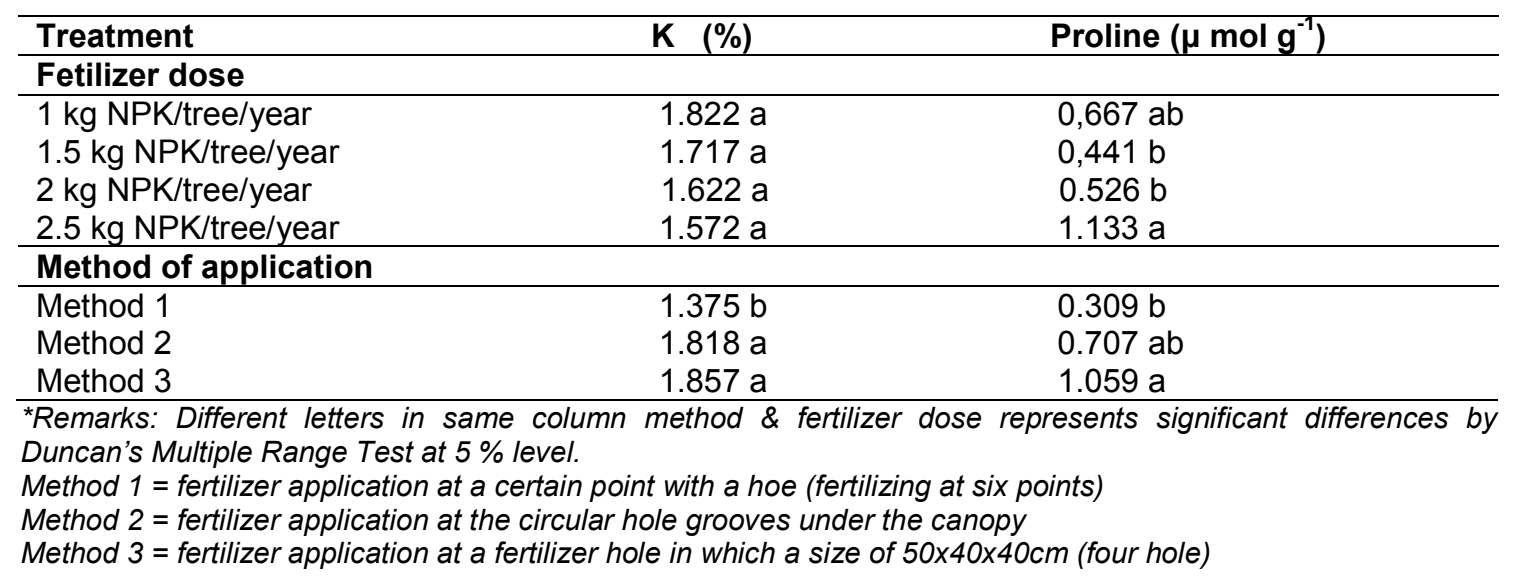

practice (a new management practice) of apple plants [24]. The increase in vegetative growth, plant biomass accumulation in NPK applications at certain doses is due to increased nutrient absorption, accumulation of nutrients such as $\mathrm{N}$ in roots, $P$ in stems, and $K$ in leaves, and an increase in chlorophyll content [25]. This is in line with the results of the research presented in Table 2. The increase in leaf $\mathrm{N}$ and $\mathrm{P}$ content (Table 2) was significantly caused by the correct application and dosage of NPK fertilizer. The high leaf $P$ resulted from fertilizing the fertilizer in the NPK dose of $1.5 \mathrm{~kg} \mathrm{NPK/tree/year.} \mathrm{The} \mathrm{high}$ $\mathrm{N}$ content of leaves resulted from NPK fertilization into the dish with a dose of $2 \mathrm{kgNPK} /$ tree/year.

Proline is a plant-osmoprotectant-adaptation metabolic to environmental stress-osmotic stress [26], such as drought stress to avoid cell damage [27]. Thus, the presence of high chlorophyll content in fertilizer dosage treatment and optimal application method determines the ability of photosynthesis to be more optimal and avoid drought stress. In these conditions, the plant produces optimal production (fruit).

\subsection{Effect of NPK Fertilizer Treatment on the Number of Fruits}

Number of mature of fruit (big fruit) per branch and small fruit were significant $(P<0.05)$ affected by interaction of NPK fertilizer dose and application method. The treatment of method 2 application at the circular hole grooves under the canopy at a dose of $1 \mathrm{~kg}$ NPK/plant/year was recommended which gave the highest yield (Table 4). Fertilization using the method was applied into the "rorak" fertilizer hole $(40 \times 40 \times 50 \mathrm{~cm})$ with the $2 \mathrm{~kg} \mathrm{NPK} /$ plant/year dose not significantly different from fertilizing in the same way with the $2.5 \mathrm{~kg} \mathrm{NPK} /$ plant/year dose. These results indicate that the fertilization method to produce the number of fruits can be done in two manners, namely sowing in a circle in the grooves under the canopy at a dose of 1 $\mathrm{kg} \mathrm{NPK/plant/year} \mathrm{or} \mathrm{fertilizing} \mathrm{in} \mathrm{the} \mathrm{large}$ fertilizer hole $(40 \times 40 \times 50 \mathrm{~cm})$ by increasing the recommended dose $1.5-2.5 \mathrm{~kg}$ NPK/plant/year.

The use of fertilizers by sowing circular stems was more efficient in determining the number of fruits (Table 4 ). The $1 \mathrm{~kg} / \mathrm{plant} /$ year dose of NPK was effective in determining the number of fruits thought to meet the right place factors. This treatment causes the fertilizer to be absorbed more evenly by the roots. This is based on the structure and development of roots. Hardiman et al. [28] stated that the roots of forest tree species were evenly distributed in the canopy area with a lot of root biomass at a depth of 5 , 15 , and $25 \mathrm{~cm}$.

The growth of the canopy system determines the development of roots [29]. Therefore, application of fertilizer in the dish groove $5-15 \mathrm{~cm}$ deep under the canopy aims to bring the NPK element closer to the roots. With this method, the volume of fertilizer can be saved, which is only $50 \%$ of the recommended dosage (1 kg NPK/tree/year).

The dosage in this fertilization method can be applied to soils that have a neutral $\mathrm{pH}$. This was because the research location had a neutral $\mathrm{pH}$ (6.62). 
Table 4. Interaction effect of NPK fertilizer application methods and doses levels on yield parameters of nutmeg

\begin{tabular}{|c|c|c|c|}
\hline Methods & Doses & Number of small fruits $/$ branch & Number of big fruits "/branch \\
\hline Method 1 & $1 \mathrm{~kg} \mathrm{NPK} /$ tree/year & $11.0 \mathrm{~cd}$ & $33.4 \mathrm{~b}-\mathrm{e}$ \\
\hline Method 1 & $1.5 \mathrm{kgNPK} /$ tree/year & $22.9 \mathrm{bd}$ & $48.5 a-d$ \\
\hline Method 1 & $2 \mathrm{kgNPK} /$ tree/year & $13.4 \mathrm{~cd}$ & $31.3 \mathrm{c}-\mathrm{e}$ \\
\hline Method 1 & 2.5NPK/tree/year & $9.7 \mathrm{~d}$ & $33.4 \mathrm{de}$ \\
\hline Method 2 & $1 \mathrm{~kg} \mathrm{NPK} /$ tree/year & $109.0 \mathrm{a}$ & $71.4 \mathrm{a}$ \\
\hline Method 2 & $1.5 \mathrm{kgNPK} /$ tree/year & $4.0 \mathrm{~d}$ & $14.0 \mathrm{e}$ \\
\hline Method 2 & $2 \mathrm{kgNPK} /$ tree/year & $30.7 \mathrm{~b}-\mathrm{d}$ & $31.7 \mathrm{~b}-\mathrm{e}$ \\
\hline Method 2 & 2.5NPK/tree/year & $9.2 \mathrm{~cd}$ & $11.3 \mathrm{e}$ \\
\hline Method 3 & $1 \mathrm{~kg} \mathrm{NPK} /$ tree/year & $17.7 \mathrm{~cd}$ & $62.0 \mathrm{ab}$ \\
\hline Method 3 & $1.5 \mathrm{kgNPK} /$ tree/year & $26.0 \mathrm{~b}-\mathrm{d}$ & $38.7 \mathrm{ad}$ \\
\hline Method 3 & $2 \mathrm{kgNPK} /$ tree/year & $33.5 \mathrm{bc}$ & $55.7 \mathrm{ac}$ \\
\hline Method 3 & 2.5NPK/tree/year & $62.5 a b$ & $70.0 \mathrm{a}$ \\
\hline
\end{tabular}

${ }^{*}$ Remarks: Different letters in same column method \& fertilizer dose represents significant differences by Duncan's Multiple Range Test at $5 \%$ level.

Method $1=$ fertilizer application at a certain point with a hoe (fertilizing at six points)

Method 2 = fertilizer application at the circular hole grooves under the canopy

Method $3=$ fertilizer application at a fertilizer hole in which a size of $50 \times 40 \times 40 \mathrm{~cm}$ (four hole)

Small fruit has a diameter of 2.5--3,5cm and leaf green color (Fig. 1).

Big fruit are fruits with a diameter of $4 \mathrm{~cm}$ and yellow flesh skin (old fruit flesh) 
Table 5. Correlation of leave physiological traits and yield components

\begin{tabular}{|c|c|c|c|c|c|c|c|c|c|c|}
\hline & $\begin{array}{l}\text { Chlorophyll } \\
\text { a (a) }\end{array}$ & $\begin{array}{l}\text { Chlorophyll } \\
\text { b (b) }\end{array}$ & $\begin{array}{l}\text { Total } \\
\text { Chlorophyll } \\
\text { (c) }\end{array}$ & NRA (d) & $\mathbf{N}(\mathbf{e})$ & $P(f)$ & $K(g)$ & $\begin{array}{l}\text { Proline } \\
\text { (h) }\end{array}$ & $\begin{array}{l}\text { Number of } \\
\text { small fruits } \\
\text { (i) }\end{array}$ & $\begin{array}{l}\text { Number of big } \\
\text { fruits (j) }\end{array}$ \\
\hline$a$ & & & & & & & & & & \\
\hline$b$ & $0.971^{* *}$ & 、 & & & & & & & & \\
\hline c & $0.973^{* *}$ & $0.978^{* *}$ & & & & & & & & \\
\hline d & $-0.116 n s$ & $-0.162 n s$ & $-0.160 n s$ & & & & & & & \\
\hline e & $-0.322 n s$ & $-0.339 n s$ & $-0.389 n s$ & $0.489 \mathrm{~ns}$ & & & & & & \\
\hline$f$ & $0.583^{*}$ & $0.528 \mathrm{~ns}$ & $0.605 \mathrm{~ns}$ & $-0.256 n s$ & $-0.225 n s$ & & & & & \\
\hline g & $-0.174 n s$ & $-0.193 n s$ & $-0.066 n s$ & $0.2020 \mathrm{~ns}$ & $0.126 n s$ & $0.141 \mathrm{~ns}$ & & & & \\
\hline $\mathrm{h}$ & $-0.117 n s$ & $-0.031 \mathrm{~ns}$ & $0.004 \mathrm{~ns}$ & $0.0972 \mathrm{~ns}$ & $-0.334 n s$ & $0.238 \mathrm{~ns}$ & $0.271 \mathrm{~ns}$ & & & \\
\hline i & $0.008 n s$ & $-0.031 \mathrm{~ns}$ & $0.061 \mathrm{~ns}$ & $-0.271 \mathrm{~ns}$ & $0.038 \mathrm{~ns}$ & $-0.231 \mathrm{~ns}$ & $0.270 \mathrm{~ns}$ & $-0.119 n s$ & & \\
\hline j & $0.615^{\star *}$ & $0.663^{*}$ & $0.634^{*}$ & -0.17811 & 0.15074 & $0.211 \mathrm{~ns}$ & $0.082 \mathrm{~ns}$ & $-0.046 n s$ & $0.748^{* *}$ & \\
\hline
\end{tabular}
**: Very significant diferrence; *: Significant diffrence; $n s:$ Non significant 


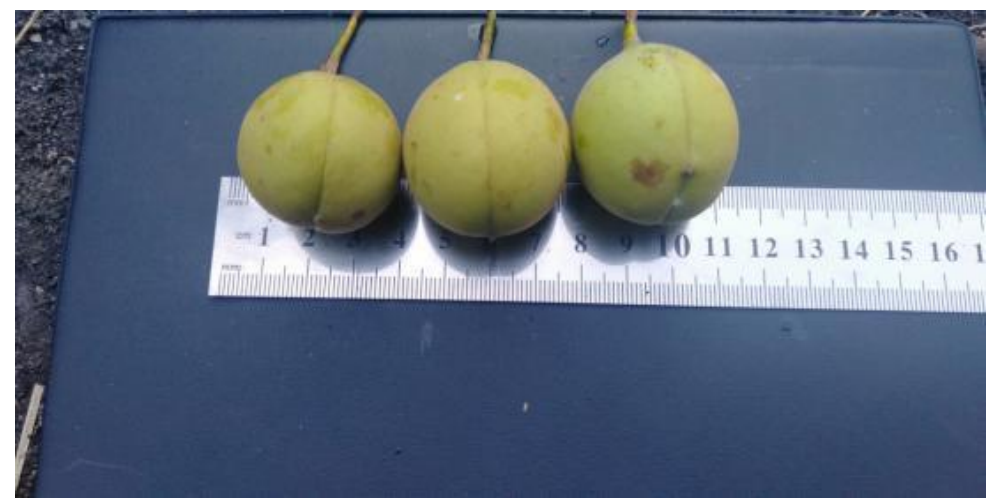

Fig. 1. Fruit of nutmeg is small size

On soil that is difficult to make a circular disc under the canopy, especially in rocky and sloping areas, fertilizing the nutmeg is done by placing it in the "rorak" fertilizer hole. This treatment is still optimal because it gives a high yield of old fruit (Table 4). A higher dose of NPK (15:15:15) is required because only the surface area of the roots around the planting hole will absorb.

\subsection{Correlation of Leaf Physiological Traits and Yield Components}

There was a positive correlation of number of big fruit with chlorophyll a, chlorophyll b, total chlorophyll and number of small fruit. Leaf content of proline and NRA did not show positive corelation with number of big fruit, in fact, these two parameters negatively affected the number of old fruits (Table 5). This result indicated that number of big fruit at 8 months after fertilizer treatment caused the higher of leave chlorophyll content and number of small fruit.

The high proline activity had a negative effect on the number of mature fruits. This was because proline is a type of protein that is formed when plant depressed by drought. The catabolism of protein molecules into proline causes fruit formation to be disrupted. Meanwhile, the high NRA had a negative effect on the number of old fruits, presumably because the NRA played a role in vegetative growth. Application a source of nitrate ( $\mathrm{N}$ fertilizer) when the plants begin to form fruit will interfere with the formation of old fruit.

The relationship between chlorophyll and production (number of fruits) is very close (Table $5)$. The positive correlation of the chlorophyll $a$, chlorophyll b, and total chlorophyll content with the number of old fruits, respectively was $0.665^{\star *}, 0.663^{*}$ and $0.634^{*}$. These results indicate that the physiological traits of the leaves (chlorophyll) which are influenced by fertilization determine the fruit yield. These results were in line with the Mensah et al. [23] that NPK fertilization (15:15:15) at a certain dose range significantly increased the number of leaves, plant height, and leaf area of the Punica granatum plant. This is because chlorophyll plays a role in producing photosynthate (source) which is allocated for fruit formation (sink) or sourcesink relationships [30].

\section{CONCLUSION}

The fertilization treatment with the fertilizer application method into the crack/hole fertilizer with a dose of $2.5 \mathrm{~kg} \mathrm{NPK}$ (15:15:15) significantly produced high levels of chlorophyll a, chlorophyll $b$, total chlorophyll of leaves and old fruit. The content of chlorophyll a, chlorophyll b, and total levels had a positive correlation with the number of old fruits, namely $0.665^{* *}, 0.663^{*}$, and 0.634 ${ }^{*}$, respectively. Fertilizer application into the rorak also caused the plant to create a defense mechanism against drought stress (water limitation) indicated by a significant increased in leaf proline activity. On sloping land, the fertilizer application method can be done by sowing in a circular plate of stems under the canopy at a dose of NPK (15:15:15) $1 \mathrm{~kg} / \mathrm{plant} /$ year because it gave higher yields of old fruit.

\section{ACKNOWLEDGEMENTS}

The authors acknowledge the laboratory assistant of Plant Science of Universitas Gadjah Mada Yogyakarta Indonesia, Faculty of Agriculture, Agriculture-plantation office of North Halmahera Regency. The author also expresses his gratitude and appreciation to the farmers who own the main nutmeg gardens. The author 
acknowledge to Assessment Institute for Agricultural Technology (AIAT) for funding with DIPA 2019.

\section{COMPETING INTERESTS}

Authors have declared that no competing interests exist.

\section{REFERENCES}

1. Anonymous. Statistik Perkebunan Indonesia: Tree crop estate statistic of Indonesia 2017-2019: Pala: Nutmeg. Directorate General of Estate Crops. Ministry of Agriculture; 2018.

Accessed: 23 September 2021.

Available:http://www.ditjenbun.pertanian.g o.id/?publikasi=buku-statistik-kelapa-sawitpalm-oil-2011-2013.

2. Yousaf M, Li J, J. Lu J, Ren T, Cong R, Fahad S, Li X. Effects of fertilization on crop production and nutrient-supplying capacity under rice-oilseed rape rotation system. Scientific Report. 2016;7(1270): 1-9.

3. Burducea MB, Zheljazkov VD, Dincheva I, Lobiuc A, Teliban GC, Stoleru V, Zamfirache MM. Fertilization modifies the essential oil and physiology of basis varities. Industrial Crops and Product. 2018;12(1):282-93.

4. Bistgani ZE, Siadat SA, Bakhshandeh A, Pirbalouti AG, Hashemi M, Maggi F, Morshedloo MR. Application of combined fertilizers improves biomas, issential oil yield, aroma profile, and antioxidant properties of Thymus daenensis Celak. Industrial Crops and Product. 2018;121 (1):434-40.

5. Boroomand $\mathrm{N}, \quad$ Grouh $\mathrm{MSH}$. medicinal plants: A review. Journal of Medicinal Plants Researc. 2012;6(12): 2249-55.

6. Meng W, Ming L, Jia L, Wei-tao L, Chunyu J, Zhong-pei L. Optimize nitrogen fertilization location in root-growing zone to increase grain yield and nitrogen use efficiency of transplanted rice in subtropical China. Journal of Integrative Agriculture. 2017;16(9):2073-81.

7. Tsialtas IT, Shabala S, Baxevanos D, Matsi T. Effect of potassium fertilization of leaf physiology, fiber yield and quality in Catton (Gossypium hirsutum L.) under irrigated mediterranean conditions. Field Crops Research. 2015;193.
8. Abdul-Hamid $\mathrm{H}$, Yusoff $\mathrm{MH}$, Ab-Shukor NA, Zainal B, Musa MH. Effects of different fertilizer application level on growth and physiology of Hibiscus cannabinus L. (kenaf) planted on BRIS soil. Journal of Agricultural Science. 2009;1(1):121-31.

9. Sulistiono W, Brahmantiyo B, Hartanto S, Aji HB, Bina HK. Effect of arbuscular mycorrhizal fungi and NPK fertilizer on roots growth and nitrate reductase activity of coconut. J. Agron. 2020;19(1):46-53.

10. Vaidehi G, Subramanian S, Adeline Vinila JE. Influence of fertilizer levels on growth, yield and Economics of nutmeg (Myristica fragrans. Houtt). Plant Archives. 2017; 17(1):201-06.

11. Yoshida S, Forno DA, Cock JH, Gomez $\mathrm{KA}$. Laboratory manual for physiological studies of rice". Second Edition. Los Banos. IRRI. Laguna, Philippines. 1997; 70.

12. Wintermants JFGM, De Monts AS. Spectrophotometric characteristics of chlorophylls $a$ and $b$ their pheophytins in etanol. Biochim Biophys Acta (Amst.). 1965;109:448-53.

13. Indradewa D, Sastrowinoto S, Notohadisuwarno $\mathrm{S}$ dan Prabowo $\mathrm{H}$. Metabolisme nitrogen pada tanaman kedelai yang mendapat genangan dalam parit. ,Ilmu Pertanian. 2004;11(2):68-75.

14. Bates LS, Waldren RP, Teare ID. Rapid determination of free proline for water stress studies. Plant Soil. 1973;39:205-07.

15. Špuláka, Martincováa J, Vítámvásb J, Kuneš I. The effect of fertilization on chlorophyll activity, content of photosynthetically active pigments and nutrients in Carpathian birch Leaves. Austrian Journal of Forest Science. 2014; 1:23-44.

16. Long JR, Ma GH, Wan $Y Z$, Song CF, Sun $J$, Qin RJ. Effect of nitrogen fertilizer level on chlorophyll fluresence, characteristics in flag leaf of super hibrid rice at late growth stage. Rice Science. 2013;20(3):220-28.

17. Kapoor D, Bhardwaj S, Landi M, Sharma A, Ramakrishnan M, Sharma A. The impact of drought in plant metabolism: How to exploit tolerance mechanisms to increase crop production. Appl Sci. 2020; 10(5692):1-19.

18. Mafakheri A, Siosemardeh A, Bahramnejad B, Struik PC, Sohrabi Y. Effect of drought stress on yield, proline and chlorophyll contents in three chickpea 
cultivars. Australian Journal of Crop Science. 2010;4(8):580-85.

19. Chun SC, Paramasivan M, Chandrasekaran M. Proline accumulation inflfluenced by osmotic stress in arbuscular mycorrhizal symbiotic plants. Frontiers in Microbiology. 2018;9(2525):1-13.

20. Karwata $H$, Sparkea MA, Rasche $F$, Arango J, Nuñez J, Rao I, Moreta D, Cadisch G. Nitrate reductase activity in leaves as a plant physiological indicator of in vivo biological nitrification inhibition by Brachiaria humidicola. Plant Physiology and Biochemistry. 2019;137:113-20.

21. Cazetta JO,Villela LCV.Nitrate reductase activity in leaves and stems of tanner grass (Brachiaria radicans Napper). Sci. Agric. (Piracicaba, Braz.). 2004;61(6):64048.

22. Santos RL, Freire FJ, Oliveira ECA,Freire MBGS, West JB,Barbosa JA, Moura MJA, Bezerra PC. Nitrate reductase activity and nitrogen and biomass accumulation in sugarcane under molybdenum and nitrogen fertilization. Rev Bras Ciênc. 2019;43:1-19.

23. Mensah ST, chekwu EB, Mgbedo UG, Uzoma MC. Effect of N: P: K (15: 15: 15) on the Growth of Punica granatum L. Seedlings. International Journal of Agronomy. 2020;4653657:1-7.

24. Milošević T, Milošević N. Apple fruit quality, yield and leaf macronutrients content as affected by fertilizer treatment. Journal of Soil Science and Plant Nutrition. 2015;15(1):76-83.

25. Deng S, Shi K, Ma J, Zhang L, Ma L, Jia Z. Effects of Fertilization Ratios and Frequencies on the Growth and Nutrient Uptake of Magnolia wufengensis (Magnoliaceae). Forests. 2019;10(65): 1-29.

26. Pavlović D, Nikolić B, Đurovi S, Waisi H, Anđelković A, Marisavljević D. Chlorophyll as a measure of plant health: Agroecological aspects, Pestic. Phytomed. (Belgrade). 2014;29(1):21-34.

27. Hörtensteiner S, Kräutler B. Chlorophyll breakdown in higher plants. Biochimica et Biophysica Acta. 2011;1807:977-88.

28. Hardiman BS, Gough CM, Butnor JR, Bohrer G, Detto M, Curtis PS. Coupling fine-scale root and canopy structure using ground-based remote sensing. Remote Sens. 2017;9(182):1-13.

29. Tomasi, Gaiotti F, Petoumenou D, Lovat L, Belfifiore N, Boscaro D, Mian G. Winter pruning: Effect on root density, root distribution and root/canopy ratio in Vitis vinifera cv. pinot gris. Agronomy. 2020;10 (1509):1-16.

30. Fischer G, Merchán PJA, Ramírez F. Source-sink relationships in fruit species: $A$ review. Revista Colombiana de Ciencias Hortícolas. 2012:6(2):238-53.

(c) 2021 Sulistiono et al.; This is an Open Access article distributed under the terms of the Creative Commons Attribution License (http://creativecommons.org/licenses/by/4.0), which permits unrestricted use, distribution, and reproduction in any medium, provided the original work is properly cited. 